\title{
KLASICISTINIO STILIAUS PARKŲ MENO TENDENCIJOS BEI RAIDA EUROPOJE IR LIETUVOJE
}

\author{
Albinas Mocevičius \\ Architektūros pagrindų ir teorijos katedra, Vilniaus Gedimino technikos universitetas, \\ Pylimo g. 26/Trakug. 1, LT-01132 Vilnius, Lietuva, \\ El.paštasamocevicius@yahoo.com
}

Iteikta 20090623

Santrauka. Straipsnyje trumpai aptariama klasicistinio stiliaus parkų meno raida bei tendencijos XVII a. pab. XIX a. pr. Europoje ir Lietuvoje. Didžiausias dėmesys kreipiamas į klasicistinio stiliaus bendrąsias atsiradimo priežastis, raidos ypatumus ir pokyčius, kurie buvo juntami po prieštaringai vertinamos Baroko epochos. Remiantis to meto Europos valstybèse (Prancūzijoje, Anglijoje, Vokietijoje, Rusijoje ir Lenkijoje) sukurtų klasicistinio stiliaus parkų ansamblių bendrais bruožais, planine ir erdvine struktūra, bandoma surasti sąsajų ir išskirtinumo požymių Lietuvos parkuose. Trumpai apžvelgiami Europos šalių kraštovaizdžio ir gamtos mokslų specialistų teoriniai bei praktiniai darbai, kurie buvo reikšmingi kuriant naujojo stiliaus parkus. Taip pat straipsnyje atkreipiamas demesys ị ne visai tiksliai vartojamus terminus lietuviškoje literatūroje, apibūdinančius klasicistinio stiliaus parkus, pateikiama trumpa santrauka apie reikšmingiausius sukurtus ir perplanuotus Lietuvos klasicistinio stiliaus parkus.

Reikšminiai žodžiai: klasicizmas, parkų meno tendencijos, kraštovaizdiniai parkai, kompoziciniai elementai, akcentai, želdynai.

\section{Ivadas}

Meno istorijoje ir menotyroje visada buvo sunku kategoriškai teigti ar nustatyti aiškią meno formos ar stiliaus raidos pradžią ir pabaigą. Mene vyksta nenutrūkstama evoliucija, kurią galima suprasti iš atskirų stilių laikotarpių, bandant sudèlioti chronologiškai, bet nenubrèžiant griežtų matematinių ribų. Daugeliu atvejų, jeigu dabartiniai meno kūriniai „dalyvavo“ istorijos procese, būtų sunku priskirti juos tik vienam meno stiliui. Jei kalbèsime apie architektūros istoriją ir stilius, pavyzdžiui, nuo vèlyvosios antikos, datuoti konkrečiais metais vieną ar kitą stilių būtų neịmanoma ir neteisinga. Mene stiliai laisvai ir palaipsniui pereidavo nuo vieno prie kito. Šioje raidoje netgi atsirasdavo pereinamųjų stilių tarpsnių. Menininkai savo kūryboje neretai ịkūnydavo kelių stilių sintezę. Todèl analizuojant ir pateikiant konkretaus stiliaus raidą, atsiradimą ir jo sunykimą netikslu būtų pradèti nuo metų ar vietos (Belting 2002). Naujos idejos mene skleidèsi palaipsniui, tam tikru laikotarpiu arba kokiame nors meno kūrinyje jos buvo išgryninamos. Jei kalbėsime apie klasicistinị stilių (lot. classicus - pavyzdinis) meno istorijoje, chronologiškai šis stilius išsirutuliojo iš baroko. Meno tendencijų pokyčiai naujuoju laikotarpiu buvo akivaizdūs - įsivyravo racionalumo, aiškumo, grynumo, antikos renesanso meniniai kriterijai.

\section{Klasicistinio stiliaus ištakos ir paplitimas Europoje}

Istorijoje klasicistinis stilius atsirado XVII a. pab. XVIII a. pr. absoliutizmo klestejjimo laikotarpiu Europoje (Ado ir kt.1975). Nors šiame straipsnyje svarbiau ne išsiaiškinti, kada tiksliai ir kur atsirado šis stilius, o pateikti klasicistinio stiliaus atsiradimo priežastis mene, estetikos teorijos supratimą ir konkrečiau - kraštovaizdžio architektūros raidą šiuo laikotarpiu, klasicistinio stiliaus parkų meno tendencijas Vakarų ir Rytų Europoje bei Lietuvoje. 
Barokiniam stiliui pasiekus apogejų, ivairiose meno srityse pradeda rastis sąlygiškai naujų idèjų. Jos skirtingai reiškiasi dailèje, literatūroje, muzikoje, teatre, architektūroje ar planuojant miestus. Kaip ir kiekviena visuomeninè ar ekonominè santvarka, taip ir meno stiliai po tam tikro laikotarpio pradedami kritikuoti ir nenumaldomai turi keistis arba žlugti. Barokas buvo ne išimtis. To meto visuomenëje brendo nepasitenkinimas pernelyg neracionaliu, eksperimentiniu ir puritonišku valstybių ir monarchų gyvenimu. Visose visuomenès gyvenimo srityse pasigendama racionalumo, tvarkos, prasmingumo.

Kritikos banga XVII a. labiausiai pradeda jaustis teatro, literatūros kūriniuose. Dailèje ir architektūroje menininkai ieško naujų kūrybos impulsų, siekia prigesinti ekstravagantiško stiliaus protrūkị.

Architektūroje atsigręžiama ị antikos meną ir jo principus, dailèje prisimenama gamta, literatūroje ir teatre atsiranda naujų žanrų ir kanonų, kūriniuose kritikuojama monarchija, skleidžiamas švietejjiškas gyvenimo būdas ir t. t.

Šiems pokyčiams meno istorijoje turi itakos Europos valstybių monarchų varžymasis tarpusavyje, valdymo politikos ir estetikos suvokimo praradimas (Gombrich 1995).

Naujojo stiliaus - klasicistinio - sklaida Europoje pradejjo plisti iš Italijos (antikos meno principai), iš Anglijos (konstitucinès monarchijos restauracija, novatoriškų idejjų plètros galimybės) ir sparčiausiai pasireiške Prancūzijoje (Baroko epochos viršūnè, politinio ir socialinio gyvenimo pokyčiai visuomenejje) (Benevolo 1998).

Šios sklaidos ypatybès turèjo didelès ịtakos tolesnei klasicistinio stiliaus architektūros, parkų meno raidai ir tendencijoms.

Naujosios klasicizmo idejjos architektūroje buvo paremtos antikos meno principais ir kanonais, o parku menas buvo kuriamas dviem kryptimis: prancūziškąja ir angliškąja. XVII a. vid. ir pab. žemyninejje Europoje tobulinami ir plečiami prancūziškojo barokinio stiliaus parkai, o Anglijoje XVII a. pab. - XVIII a. pr. kuriami klasicistinio stiliaus parkai.

Kadangi Prancūzijoje, Vokietijoje, Lenkijoje ir kitose to meto valstybèse buvo paplitusios Baroko epochos meno tendencijos, naujasis meno stilius sunkiai „skynèsi“ sau kelią. Anglijoje priešingai - naujos idèjos sklido mene ir visuomeniniame gyvenime labai sparčiai ir sklandžiai, be pasipriešinimo. Ko gero, ne vien tik dèl politinių priežasčių (konstitucinè monarchija), bet ir dèl estetinių (priešprieša prancūziškajam barokui) (Bumblauskas 2005). Anglams buvo priimtines- nis antikos menas nei puošnus prabangusis barokas. Filosofo J. J. Rousseau teiginiuose atkreiptas demesys ì natūralaus kraštovaizdžio vertybes, jos supriešinamos su formaliu teritoriju geometrizavimu (Vanagas 2003). Naujasis klasicistinis stilius Anglijoje turèjo tvirtą pagrindą - paladianizmą, kuris tuo metu buvo paplitęs miestų ir užmiesčio vilų, žemvaldžių rūmų architektūroje. Šiuo laikotarpiu Anglijoje labai domimasi Renesanso laikotarpio architekto, teoretiko Andrea Palladio (1508-1580 m.) idejomis, išdèstytomis traktate Quattro Libri dell'Architettura (1570), kuriame aukštinamos antikos ir Renesanso idejos (JakovlevasMateckis 2008). XVIII a. Paladijaus knyga ir kūriniai (Villa Barbaro Italijoje, XVI a.) (The Garden book 2000) buvo didžiausias autoritetas visais architektūrinio skonio ir architektūros taisyklių klausimais. Suprojektuoti užmiesčio vilą Paladijaus kanonais buvo mados ir gero skonio išraiška (Gombrich 1995) (1 pav.).

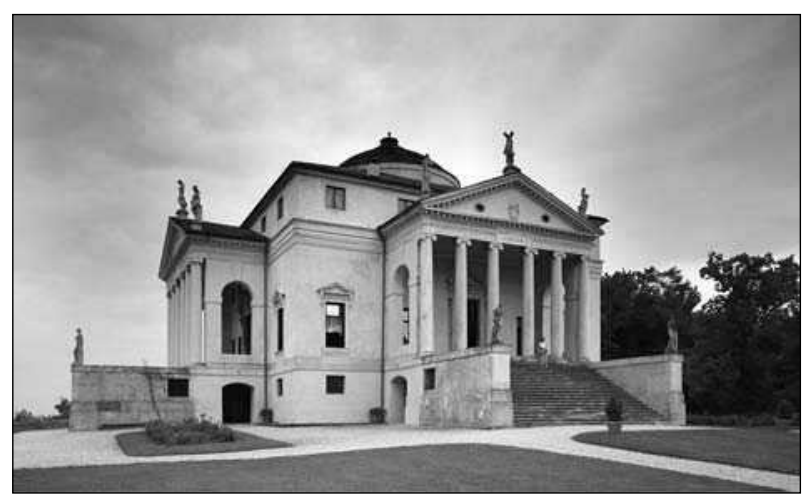

1 pav. Klasikinis Paladijaus vilos modelis, daręs j̇taką klasicistinio stiliaus rūmų architektūrai (Villa Capra, XVI a.)

Fig. 1. Classical model of Paladis Villa which had an influence on architecture of classicism style (Villa Capra, $16 \mathrm{c}$ )

\section{Klasicistinio stiliaus parky meno tendencijos Europoje}

Klasicistinio stiliaus parkai XVIII a. pr. projektuojami pagal aiškiai nusakomus kriterijus - sąmoningai atsisakant taisyklingo perspektyvinio plano (buvo būdinga barokinio stiliaus parkams). Naują ir ryškų postūmị parkų meno raidai padarè minèti parkų komponavimo pokyčiai šiuo laikotarpiu (Hobhouse 2002). Naujosios meno tendencijos akivaizdžios šiuose Anglijos parkuose: Badmintone (1682), Chesworthe (1685), Melburn Hole (1704-1711), Stowe parke (1738) (2, 3 pav.). Pastarasis buvo perprojektuotas iš barokinio stiliaus, autorius W. Kent. Garsiausi klasicistinio 


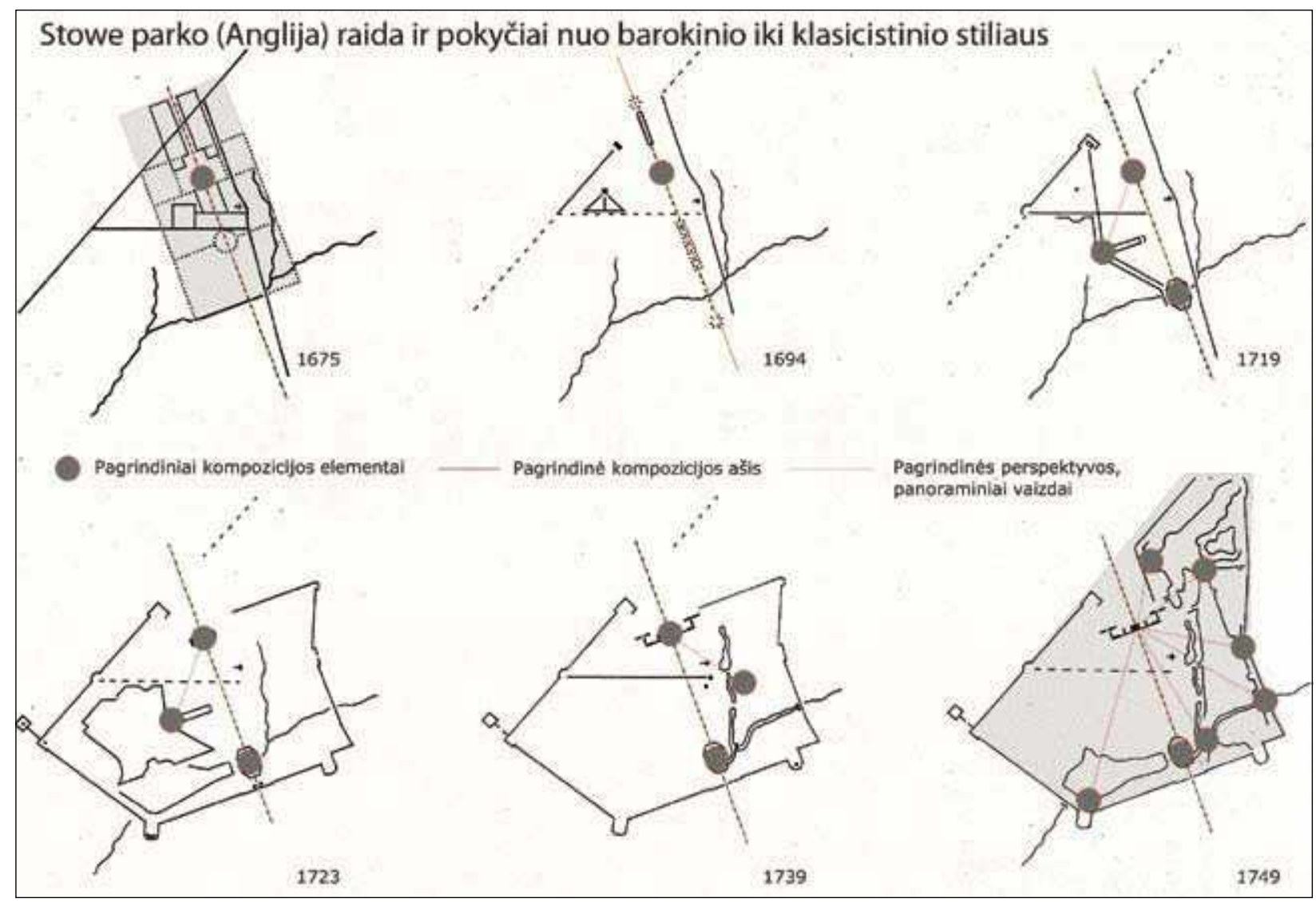

2 pav. Stowe parko raida ir pokyčiai nuo barokinio iki klasicistinio stiliaus

Fig. 2. Development and changes of Stowe Park from baroque to classicism style

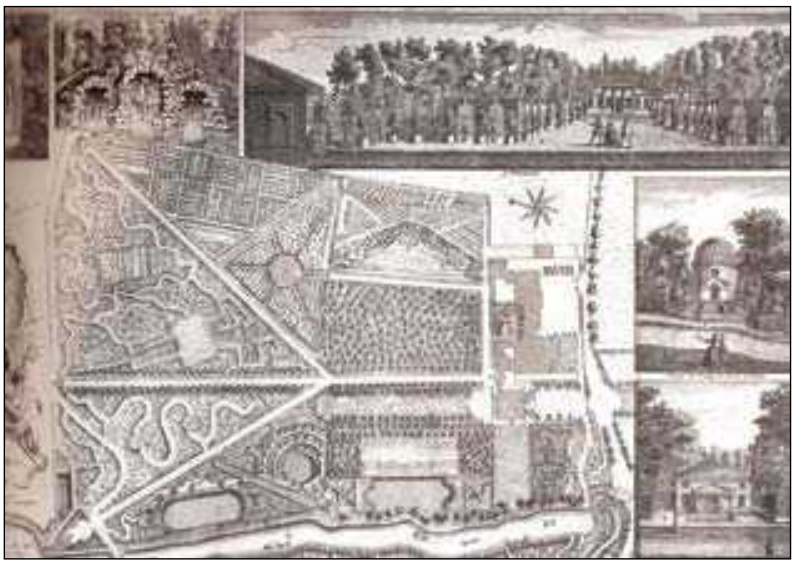

3 pav. Chesworth parko $1685 \mathrm{~m}$. planas ir perspektyvos Fig. 3. Plan and perspectives of Chesworth Park in 1685 stiliaus parkų autoriai Anglijoje buvo W. Kent, W. Chambers, H. Repton, L. Brawn. Minèti autoriai išleido ne vieną teorinị darbą, apibrèžè klasicistinio stiliaus estetinius ypatumus ir tendencijas, taisykles ir postulatus, kuriais reikètu vadovautis projektuojant parkus, nustatè sodu ir parkų skirtumus, analizavo įvairias kompoziciniu elementu formas (Kluckert 2005).

Klasicistinio stiliaus parkai projektuojami atsisakant geometrinių formų ir linijų, parko planinejje ir erdvinèje kompozicijoje akcentai tampa natūralūs ir dirbtinai sukurti vandens telkiniai, mažosios architektūros statiniai, medžių ir krūmų grupès. Šie kompoziciniai elementai buvo komponuojami tarpusavyje, kad sudarytų visumos ịspūdị ir ansamblio vientisumą.

Būdingos vaizdingose vietose pasodintos medžių, krūmų grupès, kurios perspektyvoje susilieja su natūraliai augančiu mišku. Parkuose buvo statomi antikiniai pastatai, paviljonai, kolonados, triumfo arkos, vartai (Januškevičius 2004). Mažosios architektūros formos atliko svarbų vaidmenị šio stiliaus parkams (4, 5 pav. a, b). Parkuose statiniai dažnai būdavo perspektyvos ar vietovaizdžio akcentai arba svarbios kom- 
pozicijos sudedamosios dalys. Šie svarbūs kriterijai pabrèždavo naująsias šio meno stiliaus tendencijas. Meno tendencijų kaitą lèmé doméjimasis ir botanikos mokslo atradimai, naujų želdynų ir gèlynų veislių išvedimas ir gabenimas iš svetur (pvz., Kinijos, Afrikos kolonijinių valstybių), adaptuojant prie Europos klimato (Majdecki 1993). Klasicistinio stiliaus parkų atsiradimui ir projektavimui itakos turejjo Kinijos ir Japonijos parkų meno filosofija. Anglijoje šiuos principus išdèstė W. Chambers veikale apie Rytų sodininkystę. Nors parkuose ir buvo panaudojama rytietiškų motyvų ir kompozicinių elementų (kiniški paviljonai, tilteliai, bokšteliai), pati parko filosofija nebuvo giliai suprasta ar suprasta paviršutiniškai, domino formos, o ne turinys (Жырнов 1977).

XVIII a. vid. ir pab. angliškosios parkų meno tendencijos paplito ir visoje Europoje: Prancūzijoje (po Didžiosios revoliucijos), Vokietijoje, Olandijoje, Belgijoje, Austrijoje, Lenkijoje, Rusijoje ir Lietuvoje.

XVIII a. antroje puseje suprojektuotas pavyzdinis klasicistinio stiliaus parkas Vokietijoje - Sanssouci parkų ansamblyje (6 pav., a). Šio parko autoriai P. J. Lenne ir K. F. Schinkel. Sanssouci parkų ansamblis ypatingas tuo, kad tai puikus pavyzdys, kaip sklandžiai ir palaipsniui plito naujos parkų meno tendencijos, nes dalis parko suprojektuota baroko dvasia, o dalis - klasicizmo. Autoriai, kurdami naująji Sanssouci ansambli

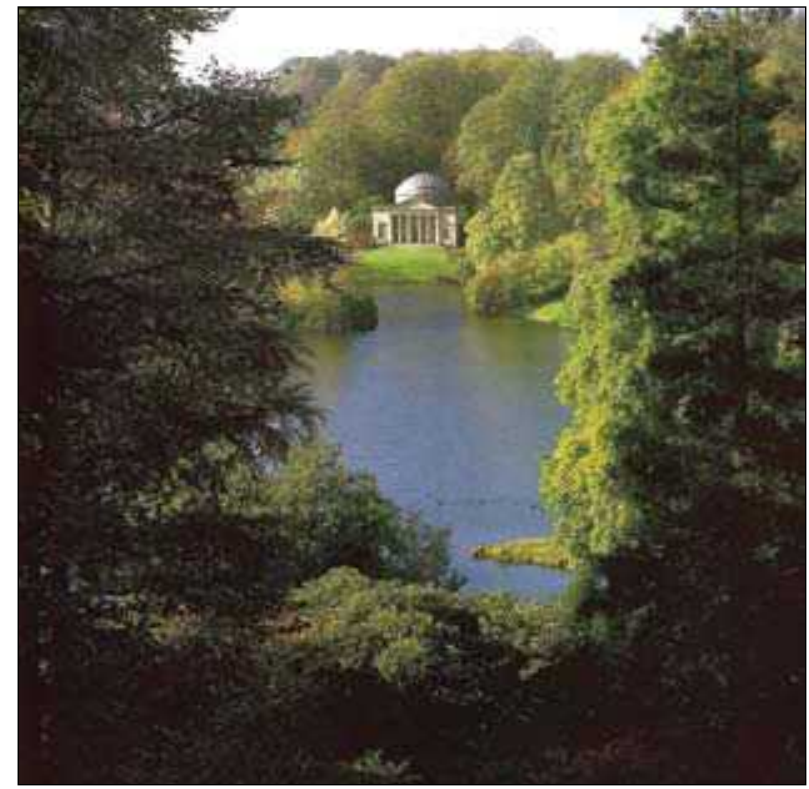

4 pav. Stourhead parkas. Perspektyvoje matyti antikinio stiliaus statinys prie tvenkinio

Fig. 4. Stourhead Park. One can see an antique-style building by the pond tarp esamų rūmų, abipus jungiančios abi parkų teritorijas alèjos suprojektavo abejus rūmus, organiškai siedami įspūdingą klasicistinio stiliaus parką su laisvo planavimo takais, atviromis parko aikštelèmis, ị parką meistriškai įkomponavo architekto K. F. Schinkel suprojektuotus klasicistinio stiliaus pastatus.

Dar vienas ryškus klasicistinio stiliaus pavyzdys Wörlitz parkas (1769-1773) (6 pav., b). Klasicistiniu stiliumi kuriami ir rekonstruojami kai kurie barokiniai Drezdeno, Potsdamo, Berlyno, Miuncheno, Kaselio parkai (Jakovlevas-Mateckis 2008).

Klasicistinio stiliaus parku meno tendencijos Rusijoje buvo įkūnytos tik XVIII a. antrojoje pusèje ir XIX a. pradžioje, nes iki tol vyravo barokinio stiliaus parkų projektavimas ir ịkūrimas. Baroko epocha Rusijoje stipriai ịsigalèjo dèl glaudžių ryšių su Prancūzija. Bet rekonstruojant ar plečiant esamus parkus, jautriai suliejami du stiliai ir jie netgi vienas kitą papildo, įsisavinamos didelès teritorijos. Klasicistinio stiliaus parkai būdavo kelis kartus didesnio ploto už esamą barokinio stiliaus parką ir išsiplèsdavo iki kelių
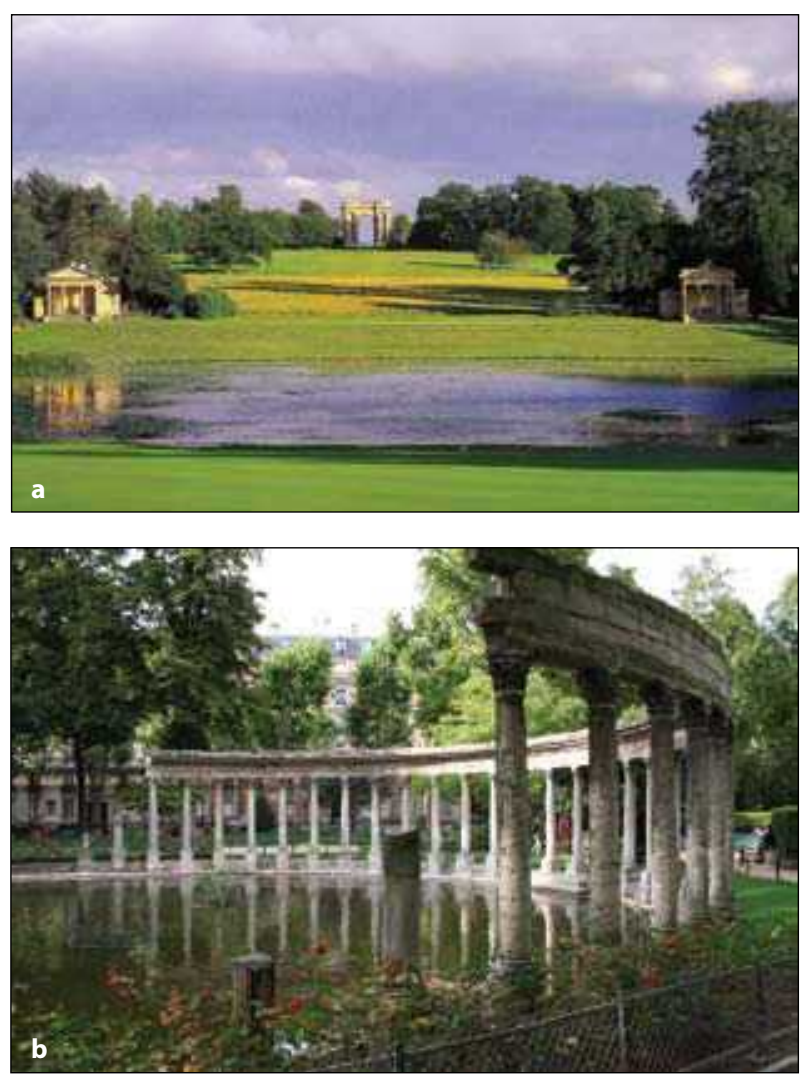

5. pav. Klasicistinio stiliaus tendencijos Anglijos Stowe (a) ir Paryžiaus Monceau (b) parkuose

Figs. 5. Tendencies of classicism style in Stowe Park in England (a) and Monceau Park in Paris (b) 

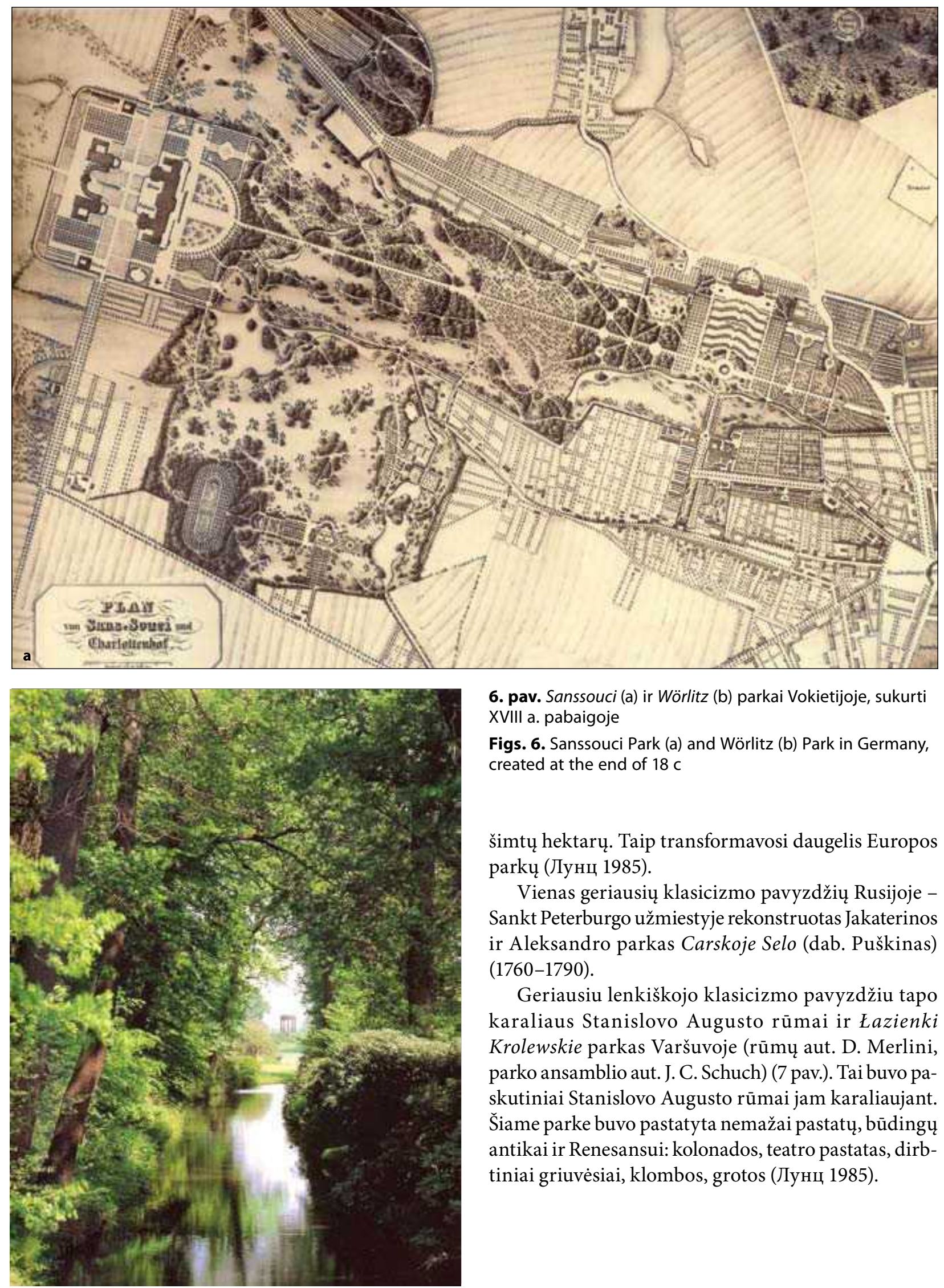

6. pav. Sanssouci (a) ir Wörlitz (b) parkai Vokietijoje, sukurti XVIII a. pabaigoje

Figs. 6. Sanssouci Park (a) and Wörlitz (b) Park in Germany, created at the end of $18 \mathrm{c}$

šimtų hektarų. Taip transformavosi daugelis Europos parkų (Лунц 1985).

Vienas geriausių klasicizmo pavyzdžių Rusijoje Sankt Peterburgo užmiestyje rekonstruotas Jakaterinos ir Aleksandro parkas Carskoje Selo (dab. Puškinas) (1760-1790).

Geriausiu lenkiškojo klasicizmo pavyzdžiu tapo karaliaus Stanislovo Augusto rūmai ir Łazienki Krolewskie parkas Varšuvoje (rūmų aut. D. Merlini, parko ansamblio aut. J. C. Schuch) (7 pav.). Tai buvo paskutiniai Stanislovo Augusto rūmai jam karaliaujant. Šiame parke buvo pastatyta nemažai pastatų, būdingų antikai ir Renesansui: kolonados, teatro pastatas, dirbtiniai griuvessiai, klombos, grotos (Лунц 1985). 


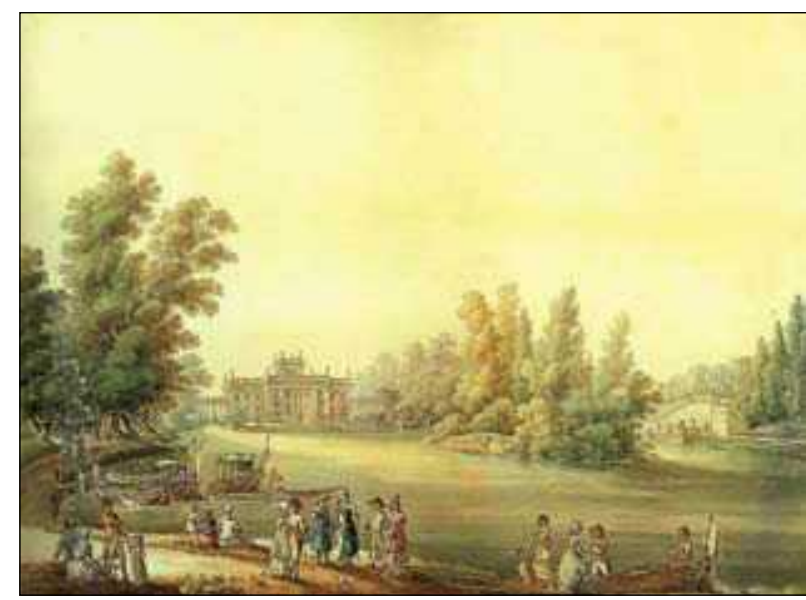

7 pav. Łazienki Krolewskie parkas Varšuvoje (Z. Vogel akvarelè, $1796 \mathrm{~m}$.)

Fig. 7. Łazienki Krolewskie Park in Warsaw (watercolour by Z. Vogel, 1796)

\section{Klasicistinio stiliaus parkų teorinè bei praktinè raida ir meno tendencijos Lietuvoje}

Lietuvoje klasicistinio stiliaus pastatai ir parkai pradedami projektuoti bei statyti apie XVIII a. vidurị. Šiam stiliui ịsigaleti mene taip pat buvo svarbios geopolitinès, ekonominès ir sociokultūrinès sąlygos. Lietuvoje atsirado naujų visuomeninių reiškinių, keitėsi vertybių kriterijai, iškilo naujų tikslų, vyko kardinalūs visuomenès idealų ir estetinių pažiūrų pokyčiai (Lietuvos architektūros istorija ... 1994). Svarbiausias ivykis tuo laikotarpiu - 1795 metų Trečiasis Lenkijos ir Lietuvos padalijimas, galutinai padalijęs valstybę tarp Austrijos-Vengrijos, Prūsijos ir Rusijos. Be abejo, nereikètų pamiršti ir neakcentuoti Šviečiamojo amžiaus estetinių ir filosofinių idèjų, plitusių iš Anglijos per Vokietijos, Lenkijos universitetus, visuomenines organizacijas, menininkus (Kulak 2006), per $1793 \mathrm{~m}$. Vilniaus universitete įkurtą Architektūros katedrą. I klasicistinio stiliaus parkų meno tendencijų raidą svarų indèlị ịnešè įsteigti Vilniaus, Gardino botanikos sodai ir juose dirbę šios srities profesoriai ir specialistai: J. E. Gilibertas (1741-1814), S. B. Jundzilas (1761-1847), J. Strumila (1774-1847), K. Podčašinskis (1790-1860) ir kt. Kaip ir Anglijoje, taip ir kitose Europos šalyse buvo leidžiami teoriniai ir apžvalginiai parkų meno specialistų darbai: G. Thouin - Plan raissonnés de toutes les espaces de jardins (1805), H. Pückler - Andeutungen über Landchaftsgärnerei (1834), I. Czartorysk Myśli rózne o sposobnie zakładania ogrodów (1805) ir kiti (Majdecki 1993). Ne išimtis buvo ir Lietuvoje J. Strumilos parengti teoriniai parku projektai, veika- las „Šiaurès sodai“, 1883 m. (Pilkauskas 2004) (8 pav.). Vilniaus universitete klasicizmo estetiką dèstė Karlas Spampanis (1740-1783) (Bumblauskas 2005).

Lietuvos klasicistinio stiliaus parkai literatūroje dažnai vadinami peizažiniais. Bet tai nèra tikslus terminas, apibūdinantis parkų meno stilistiką. Klasicistinio stiliaus parkus tiksliai apibūdina prof. habil. dr. K. Jakovlevas-Mateckis. Kraštovaizdžio architektūros profesorius siūlo šio stiliaus parkus vadinti klasicizmo kraštovaizdžio parkais, sukurtais vadovaujantis klasicizmo epochos natūralaus kraštovaizdžio formavimo principais (Jakovlevas-Mateckis 2008). Galbūt iš verstinių lenkų, rusų literatūros šaltinių pavartota ne ta terminologija, ilgą laiką buvo vartojami netikslūs terminai. Daugumos knygų, nagrinėjančių Lietuvos parkų meno stilistiką ir raidą, autoriai - ne menotyros specialistai, dèl to terminų jie išsamiau

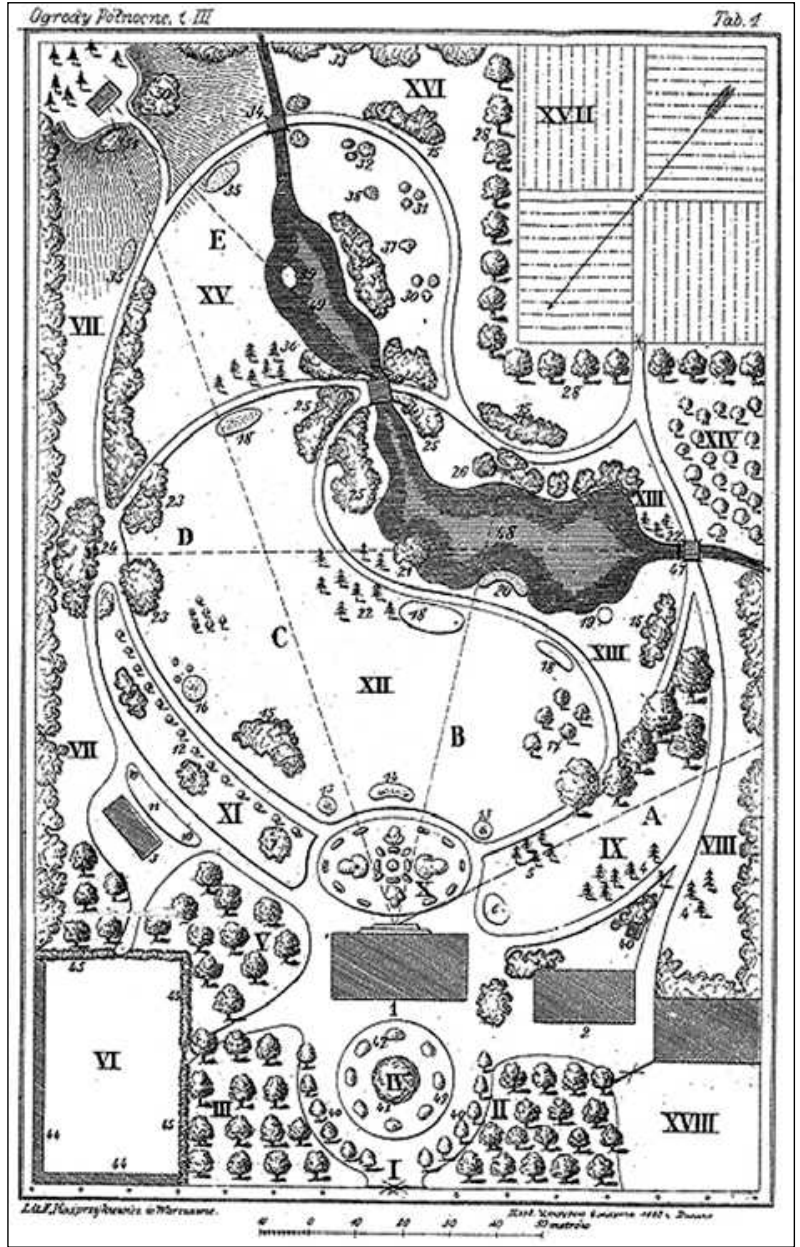

8 pav. J. Strumilos parengtas teorinis parko projektas veikale "Šiaurès sodai", $1883 \mathrm{~m}$.

Fig. 8. Theoretical park project prepared by J. Strumila in the work "Northern gardens", 1883 
neanalizavo. Kiti autoriai, rašę apie parkus, tiesiog remdavosi ankstesnių autorių darbais. Todèl siūlyčiau vadovautis tikslesniais terminais, apibūdinančiais parkų meno stilistiką, ypač nuo klasicizmo laikotarpio, kuris turèjo didelę įtaką tolesniems parkuose sukurtiems stiliams.

Lietuvoje, kaip ir Lenkijoje, klasicistinio stiliaus parkai kuriami ant barokinio stiliaus parkų pamatų arba plečiami šalia esančiose teritorijose, kurios dažniausiai integruojasi ị miškus (medžių ir krūmų grupès sodinamos ir formuojamos su esamomis grupèmis, peizažą papildo atskiri medžiai ar krūmai) arba tęsiasi iki upès ar ežero kranto. Taip buvo kuriamas vientisas ansamblis su natūraliuoju lietuvišku kraštovaizdžiu. Barokinio stiliaus fragmentai papildydavo ir sudarè vientisą stilių sintezę, kurioje struktūriškai vyraudavo klasicistinio stiliaus tendencijos. Vadovaudamiesi tais pačiais parkų projektavimo principais ir kriterijais, kaip ir Europoje, Lietuvoje kuriami analogiški parkai, gal kiek nusileidžiantys savo dydžiu ir paprastesniais komponavimo elementais. Bet buvo išlaikomos racionalumo, grynumo tendencijos, netiketo įspūdžio meniniai principai. Parkuose buvo gausu antikiniu mažosios architektūros statinių, kurie užpildydavo ir formuodavo aiškias parko erdvių kompozicijas ir daugiaplanes perspektyvas.

Klasicizmo epochos parkų meno tendencijos atskleidžiamos Verkių dvaro sodybos ansamblyje (aut. M. Knakfusas ir L. Stuoka-Gucevičius) (9 pav., a, b), Taujènų dvaro rūmuose ir parke (aut. B. Marikonis, P. de Rossi), Pakruojo parke, Kauno Aukštosios Fredos, Aštriosios Kirsnos, Joniškèlio, Šumsko, Raguvèlès, Paežerių ir kitų dvarų parkuose. Daugiausia klasicistinio stiliaus parkai buvo kuriami rekonstruojant barokinio stiliaus parkus, paliekant atskirus neesminius planavimo fragmentus prie dvaro pastatų (Plungès, Antazavès, Dotnuvos parkai). Prieš rūmus buvo paliekama reprezentacinè aikštė su privažiavimo keliukais (funkcinè paskirtis), vejos ir gèliu parteris su fontanu arba skulptūromis (estetinè paskirtis, akcentai). Už rūmų ir šonuose, perspektyvoje buvo formuojamas kraštovaizdinis parkas su klasicistiniam stiliui būdingais komponavimo elementais: lenktomis alëjomis, pasivaikščiojimų takeliais, pievelemis su atskirų želdinių (dažniausiai įvairių rūšių) grupėmis. Komponavimo principai buvo atskleidžiami atveriamomis erdvėmis i pievas, upę ar kitą vandens telkinị, sustiprinant natūralaus peizažo išraišką. Parkams buvo naudojami vietiniai lapuočiai ir spygliuočiai, svetimžemiai introdukuoti medžiai ir krūmai. Parkų teritorijose laisvas kompozicijas akcentuodavo tvenkiniai ar upeliai, kurių vagos tekèdavo pakraščiuose, aptakių formų, vingiuojančių krantų, atkartojančių takelius, tvenkiniai. Buvo mègstamos želdynų alèjos, pabrèžiančios kryptị link rūmų ar kitų dvaro pastatų, bet jos nesikirto su atviromis erdvèmis per vidurị, o ejo formuojančių želdynų grupių pakraščiais (Tauras 1989). Svarbų vaidmenị atliko teritorijos dydis (Vakarų Europoje parkų teritorija paprastai būdavo keliasdešimt kartų didesnè nei Lietuvoje), kompozicijos elementų mastelis ir sąsajos su urbanistinėmis struktūromis (nors Lietuvoje klasicistinio stiliaus parkai buvo kuriami išraiškingo reljefo vietose ir prie miestų bei miestelių, Europoje sąlytis su urbanistiniais dariniais buvo kiek kitoks, glaudžiai susijęs su visuomenès gyvenimo būdu). Bet kriterijai, būdingi klasicistinio stiliaus parkams ir jų meno tendencijoms, buvo iggyvendinami ir atskleidžiami, sukuriant bendrą ir identifikuojamą ansamblio visumą.

Trumpai apibendrindamas paplitusias klasicistinio stiliaus parkų meno tendencijas, pateiksiu keletą svar-
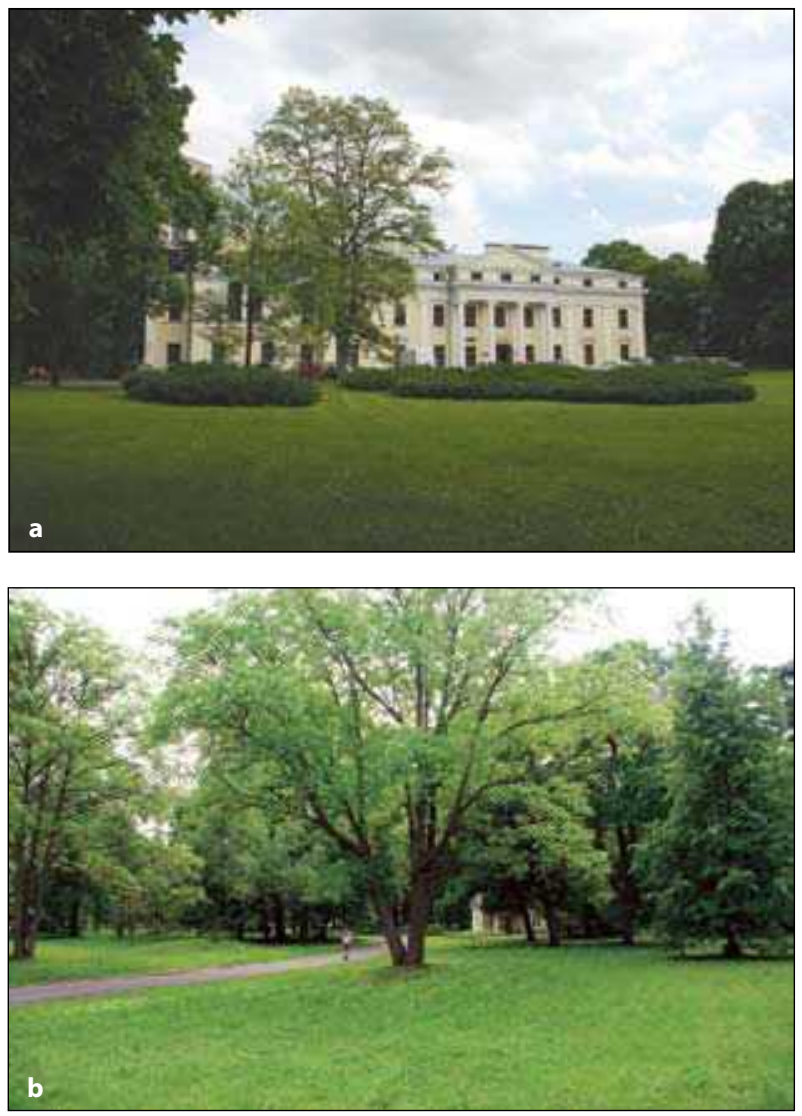

9 pav. Verkiu parko fontano vieta (a) ir lenkta aleja (b)

Figs. 9. A place for a fountain and (a) a bent alley (b) in Verkiai Park 
biausių Lietuvos teritorijoje iki mūsų dienų išlikusių charakteringiausių pavyzdžių. Vienas iš jų - Verkių parkas - ikurtas XVIII a. pabaigoje Neries dešiniajame krante ant aukštos terasos ir šlaitų. Parkas užima apie 35 ha. Iš vakarų parką juosia ị Nerị ịtekantis upokšnis su tvenkiniais. Rytinëje dalyje parkas susijungia su Žaliųjų ežerų miškais. Nuo dvaro vartų link rūmų suprojektuota lenkta alèja, kuri prisijungia prie ovalaus parterio. Akcentu priešais rūmus buvo fontanas. Aukštos parko terasos pietiniame iškyšulyje ir rytiniame pakraštyje yra apžvalgos aikštelių. Reljefo išskirtinumas (gražios Nèries terasos ir aukšti slèniai) ir struktūra, būdinga klasicizmo laikotarpiui, atskleidžia išskirtinę planinę erdvinę parko kompoziciją. Parke racionaliai sudèliotos želdynų grupès, kurios sukuria gilias perspektyvas ir išraiškingas erdves. Ǐskirtinumo suteikia kelios kompozicinès ašys ir mažosios architektūros statiniai. Parkas šiandien yra geros būklès, išsaugota klasicistinio stiliaus erdvinè planinè struktūra.

Pakruojo parkas užima 9,2 ha ploto, suprojektuotas ị šiaurę nuo klasicistinio stiliaus rūmų (10 pav., a, b). Parko peizažą paịvairina šioje vietoje platesnè Kruojos upė su juodalksniais apaugusia sala. Pasivaikščiojimams įrengti jaukūs vingiuoti parko takeliai, kuriais einant atsiveria puikūs panoraminiai vaizdai. Taip pat svarbus parko akcentas buvo arkinis tiltas su užtvanka (Semaškaitè 2008). Šis parkas taip pat vienas svarbiausių klasicistinio stiliaus parkų Lietuvoje, turi išskirtinę kompozicinę struktūrą ir būdingus šio stiliaus elementus.

Taujènų dvaro parkas buvo vienas pirmųjų, suprojektuotas Lietuvoje (aut. ir savininkas B. Marikonis, Radvilų žentas) (11 pav., a, b). Parko akcentas buvo rūmai, tvenkinių sistema, apskritas parteris su privažiavimo keliuku ir medžių alejjomis. Parkas iki šių dienų išlaikęs erdvią angliškojo parko struktūrą (Januškevičius 2004).

Kituose minètuose XVIII-XIX a. klasicistinio stiliaus parkuose buvo išsaugoti baroko bruožai ir planas aplink rūmų pastatą. Prie klasicistinio stiliaus dvaro rūmų pastato dažniausiai būdavo geometrinio plano parteris, medžių alèjos, ovalo formos privažiavimo keliukas. Šie kompozicijos elementai buvo kruopščiai prižiūrimi ir reprezentavo pastatą. Kita dalis teritorijos, dažniausiai antraeilès ansamblio vietos, buvo planuojama kraštovaizdžio parkų meno tendencijomis, laisvai formuojant želdynų kompozicijas, sufokusuojant ìvairiais kampais vietovaizdžio panoramą ir perspektyvas $i$ tvenkinius, upelių vingius. Vandens telkiniais buvo kuriamas perspektyvos gilumas, žaismingumas ir išryškinami parko akcentai, būdingi angliškojo
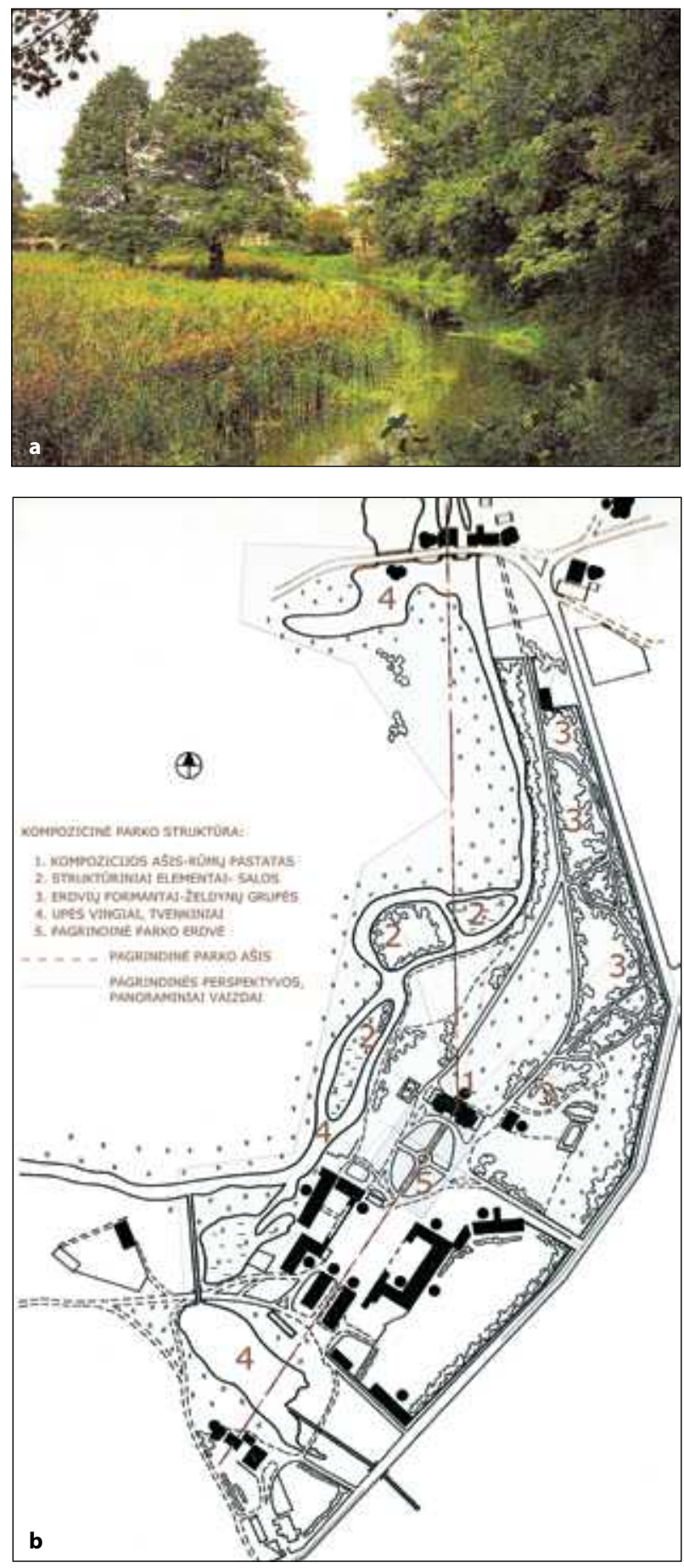

10 pav. Klasicistinio stiliaus parku meno tendencijos Pakruojo parke (a). Parko plano struktūra ir perspektyva prie upelio (b)

Fig. 10. Tendencies of classicism-style park art in Pakruojis Park (a). The structure and prospect of the Park plan by the spring (b) 

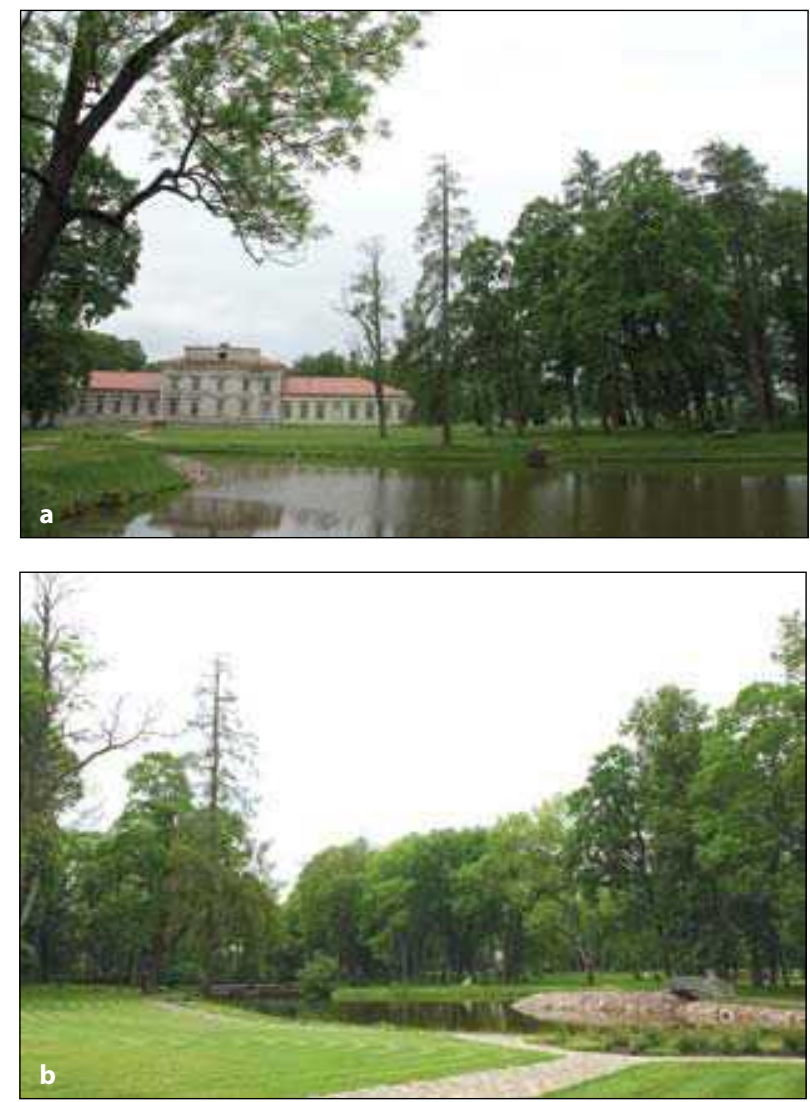

11 pav. Taujènų dvaras (a) ir parkas, sukurtas klasicizmo dvasia (b)

Figs. 11. Taujènai mansion (a) and park (b) created in classicism spirit

parko tendencijoms. Būtent tokiais kriterijais buvo vadovaujamasi projektuojant parkus ir jų ansamblius Vakarų Europoje. Meno tendencijos buvo atskleidžiamos pasitelkiant natūralios gamtos grožị ir išskirtinumą. Ivairios gamtinès, ekonominès, geopolitinès, klimatinès ir kitos darančios įtaką laikotarpio sąlygos XVIII-XIX a. Lietuvoje buvo naujo klasicistinio stiliaus kraštovaizdžio parkų meno atsiradimo ir kūrybos tendencijų formantai, atskleidžiantys nuoseklią šių meno kūrinių raidą.

\section{Išvados}

1.Istorijoje klasicistinio stiliaus tendencijos pradejjo plisti XVII a. pab. - XVIII a. pr. absoliutizmo klestéjimo laikotarpiu Europoje. Barokiniam stiliui pasiekus apogèjų, ivvairiose meno srityse pradeda atsirasti sąlygiškai naujų idejjų. Jos skirtingai reiškiasi dailèje, literatūroje, muzikoje, teatre, architektūroje ar planuojant miestus.
2. Naujojo, klasicistinio stiliaus sklaida Europoje pradèjo plisti iš Italijos (antikos meno principai), iš Anglijos (konstitucinès monarchijos restauracija, novatoriškų idèjų plètros galimybès) ir sparčiausiai pasireiškè Prancūzijoje (Baroko epochos viršūnè, politinio ir socialinio gyvenimo pokyčiai visuomenèje).

3. Klasicistinio stiliaus parkai projektuojami atsisakant tam tikrų meninių kompozicijos elementų ir kriterijų - geometrinių formų ir linijų, planiniai bei erdviniai akcentai buvo natūralūs ir dirbtinai sukurti, vandens telkiniai ir želdynų grupès natūralių formų, takeliai vingiuoti, sukuriamas gilus perspektyvos ir erdvès pojūtis gamtoje. Būdingos vaizdingose vietose pasodintos medžių, krūmų grupès, kurios perspektyvoje susilieja su natūraliai augančiu mišku. Parkuose statomi antikiniai pastatai. Klasicistinio stiliaus parkų atsiradimui ir projektavimui ịtakos turèjo Kinijos ir Japonijos parkų meno filosofija.

4. Lietuvoje klasicistinio stiliaus pastatai ir parkai pradedami projektuoti ir statyti apie XVIII a. vidurị. Šiam stiliui įsigalèti mene taip pat buvo svarbios geopolitinès, ekonominès ir sociokultūrinès sąlygos. Lietuvoje atsirado naujų visuomeninių reiškinių, keitèsi vertybių kriterijai, iškilo naujų tikslų, atsirado kardinalūs visuomenès idealų ir estetinių pažiūrų pokyčiai. Meno tendencijos panašios kaip ir Vakarų Europoje, yra tam tikrų identiteto požymių.

5. Lietuvoje klasicistinio stiliaus parkai kuriami ant barokinio stiliaus parkų pamatų arba plečiami šalia esančiose teritorijose, kurios dažniausiai integruojasi i miškus arba tęsiasi iki upès ar ežero kranto. Taip kuriamas vientisas ansamblis su natūraliuoju lietuvišku kraštovaizdžiu. Barokinio stiliaus fragmentai papildydavo ir sudarè vientisą stilių sintezę, kurioje struktūriškai vyraudavo klasicistinio stiliaus tendencijos su komponavimo principais.

\section{Literatūra}

Ado, A. ir kt. 1975. Filosofijos žodynas. Vilnius: Mintis. 213 p. Belting, H. 2002. Meno istorijos ịvadas. Vilnius: Alma Littera.

Benevolo, L. 1998. Europos miesto istorija. Vilnius: Baltos lankos.

Bumblauskas, A. 2005. Senosios Lietuvos istorija 1009-1795. Vilnius: R. Paknio leidykla.

Gombrich, E. H. 1995. Meno istorija. Vilnius: Alma Littera. Hobhouse, P. 2002. The Story of Gardening. London.

Jakovlevas-Mateckis, K. 2008. Miesto kraštovaizdžio architektūra, t. 1. Vilnius: Technika.

Januškevičius, L. 2004. Lietuvos parkai. Kaunas: Lututè. 
Kluckert, E. 2005. European garden design. From Classical Antiquity to the present day. Konemann.

Kulak, T. 2006. Wrocław. Wrocław: Wydawnictwo Dolnośląnskie.

Lietuvos architektūros istorija: nuo XVII a. pradžios iki XIX a. vidurio, t. 2. Red. koleg. pirm. A. Jankevičienè. 1994. Vilnius: Mokslo ir enciklopedijų leidykla.

Majdecki, L. 1993. Ochrona i konserwacja zabytkowych założeń ogrodowych. Warszawa: PWN.

Pilkauskas, R. 2004. Kraštovaizdžio architektūros raida Lietuvoje, iš Dailè. Kraštovaizdžio architektūra, 8-9.

Semaškaite, I. 2008. Dvarai. Spindesys ir skurdas. Vilnius: Algimantas.

The Garden book. London: Phaidon, 2000.

Tauras, A. 1989. Mūsu parkai. Vilnius: Mokslas.

Vanagas, J. 2003. Miesto teorija. Vilnius: Vilniaus akademijos leidykla.

Лунц, Л. Б. 1985. Парки мира.

Москва: Стройиздат.

Жырнов, А. D. 1977. Искусство паркостроения. Львов.

\section{TENDENCIES AND DEVELOPMENT OF CLASSICISM-} STYLE PARK ART IN EUROPE AND LITHUANIA

\section{Albinas Mocevičius}

Abstract. This paper discusses the development and tendencies of classicism-style park art at the end of the 17th and the beginning of the 19th $\mathrm{c}$ in Europe and Lithuania. Major attention is paid to general reasons of the appearance of classicism style, its special features and changes which were visible after contradictorily estimated epoch of baroque. On the basis of general features and planned and spatial structure of park ensembles in classicism of that time in such European countries as France, England, Germany, Russia and Poland, the author attempts to find correlations and special features in Lithuanian parks. The author reviews theoretical and practical works of European specialists in landscape and natural sciences, which were important in developing parks of a new style. Also, attention is drawn to some terms in Lithuanian literature which describe parks in classicism style and which are used unprecisely. A short summary of the most important created and replanned classicism-style parks in Lithuania is given.

Keywords: classicism, tendencies of park art, landscape parks, compositional elements, accents, green plantations.

\section{ALBINAS MOCEVIČIUS}

Master, doctoral student (2005), Dept of Fundamentals and Theory of Architecture, Vilnius Gediminas Technical University (VGTU), Pylimo g. 26/Traku g. 1, LT-01132 Vilnius, Lithuania. E-mail:amocevicius@yahoo.com

Master of Architecture, VGTU, 2002. Membership: member of Lithuanian Union of Architects (2003). Publications: author of 2 0publications in professional press. Projects: author or co-author of 40 realizations of projects of architectural design. Research interests: theory and practice of architecture. 